\title{
ANALISIS TINGKAT KETEPATAN WAKTU KRL COMMUTER LINE LINTAS TANAH ABANG-RANGKASBITUNG (STUDI KASUS: STASIUN JURANGMANGU)
}

\author{
Felix Jonathan Christy ${ }^{1}$, Dewi Linggasari², dan Hokbyan Angkat ${ }^{3}$
}

\author{
${ }^{1}$ Program Studi Sarjana Teknik Sipil, Universitas Tarumanagara, Jl. Letjen S. Parman No.1 Jakarta \\ Felix.325130085@stu.untar.ac.id \\ ${ }^{2}$ Program Studi Sarjana Teknik Sipil, Universitas Tarumanagara, Jl. Letjen S. Parman No.1 Jakarta \\ Dewil@ft.untar.ac.id \\ ${ }^{3}$ Program Studi Sarjana Teknik Sipil, Universitas Tarumanagara, Jl. Letjen S. Parman No.1 Jakarta \\ Hokbyan@gmail.com
}

Masuk: 06-07-2020, revisi: 28-07-2020, diterima untuk diterbitkan: 30-07-2020

\begin{abstract}
One of the modes of transportation that are of interest to the Jabodetabek community is the Kereta Rel Listrik (KRL) Commuter Line. The title of this research is the Analysis of the Level of Late Departure of the Green Line KRL Against GAPEKA at Jurangmangu Station. The purpose of this study is to identify the timeliness of Green Line KRL departures by scheduling them at Jurangmangu Station and to classify the delay level of Green Line KRL departures and determine solutions that can be applied to reduce the level of KRL Green Line late departures, especially at Jurangmangu Station. The research method used to collect data on passenger characteristics and train delays is to online survey using a questionnaire and research at the station. Delay is analyzed by Gap Analysis by comparing the time in the field and the GAPEKA. The time difference is assessed based on the tolerance of delay from the Ministerial Regulation and passenger tolerance at Jurangmangu Station. Delay tolerance according to Ministerial Regulation is 6 minutes and according to passengers is 10 minutes. The results showed that the delay of train departures at Jurangmangu Station was still below the tolerance limit for delays.
\end{abstract}

Keywords: Green Line KRL; Gap Analysis; Departure Characteristic; Punctuality

\begin{abstract}
ABSTRAK
Salah satu moda transportasi yang diminati masyarakat Jabodetabek adalah Kereta Rel Listrik (KRL) Commuter Line. Judul penelitian ini adalah Analisis Tingkat Keterlambatan Keberangkatan KRL Green Line Terhadap GAPEKA di Stasiun Jurangmangu. Tujuan penelitian ini adalah untuk mengindentifikasi ketepatan waktu keberangkatan KRL Green Line dengan penjadwalannya di Stasiun Jurangmangu serta mengklasifikasikan tingkat keterlambatan keberangkatan KRL Green Line dan menentukan solusi yang dapat diterapkan untuk mengurangi tingkat keterlambatan keberangkatan KRL Green Line terutama di Stasiun Jurangmangu. Metode Penelitian yang digunakan untuk mengumpulkan data karakteristik penumpang dan keterlambatan kereta adalah dengan survei secara online dengan menggunakan kuesioner dan penelitian langsung di stasiun. Keterlambatan dianalisis dengan Gap Analysis dengan membandingkan antara waktu di lapangan dan Grafik Perjalanan Kereta Api (GAPEKA). Kemudian perbedaan waktu tersebut dinilai berdasarkan toleransi keterlambatan dari Peraturan Menteri dan toleransi penumpang di Stasiun Jurangmangu. Toleransi keterlambatan menurut Peraturan Menteri adalah 6 menit dan menurut penumpang adalah 10 menit. Hasil penelitian menunjukkan bahwa keterlambatan keberangkatan kereta di Stasiun Jurangmangu masih di bawah batas toleransi keterlambatan.
\end{abstract}

Kata kunci: KRL Green Line; Gap Analysis; Karakteristik Perjalanan; Ketepatan Waktu

\section{PENDAHULUAN}

Kereta Rel Listrik (KRL) merupakan salah satu sarana transportasi publik yang paling banyak diminati karena cepat dan menjadi salah satu pilihan untuk menghindari kemacetan guna menghemat waktu. Kereta api memiliki jalur khusus sehingga dapat menghindari kemacetan di jalan. Untuk menaiki transportasi publik ini, pengguna perlu mengetahui beberapa informasi seperti jadwal kedatangan dan keberangkatan kereta. Dengan jadwal yang sudah ada, 
pengguna dapat memperkirakan kapan harus datang ke stasiun dan kapan kereta tersebut tiba di stasiun tujuan. Untuk jalur Tanah Abang-Rangkasbitung selanjutnya akan disebut Green Line.

Meskipun terdapat beberapa faktor yang mempengaruhi pelayanan transportasi kereta api seperti keselamatan, kemudahan layanan, kenyamanan, kecepatan, dan tarif, akan tetapi salah satu faktor yang paling banyak dikeluhkan oleh pengguna terhadap layanan KRL adalah masalah ketepatan waktu.

Waktu merupakan hal yang penting bagi kebanyakan orang, baik yang bekerja maupun pelajar. Dalam kehidupan sehari-hari banyak waktu yang terbuang di perjalanan. Arti dari nilai waktu dalam perjalanan adalah suatu faktor dalam penaksiran keuntungan atau kerugian bagi pengguna jalan. Semakin lama waktu yang dihabiskan pengguna di jalan, maka semakin banyak kerugian yang diterima pengguna. Pada kasus ini diharapkan transportasi umum khususnya KRL Jabodetabek atau KRL Commuter Line, dapat memberikan penghematan waktu pada pengguna.

Indikator utama kualitas pelayanan jasa kereta api terlihat dari angka ketepatan waktu kereta api berangkat dan datang (Kuswati). Ketepatan waktu memiliki peran yang cukup penting dan sangat dibutuhkan oleh masyarakat atau pengguna layanan kereta, sehingga pengaturan waktu yang terencana sangat diperlukan. Keterlambatan satu kereta akan sangat mempengaruhi jadwal dari kereta lain. Apalagi bila kereta yang terlambat memiliki prioritas untuk didahulukan, misalnya kereta yang terlambat adalah kereta dengan tujuan daerah yang pergerakan lalu lintasnya tinggi. Untuk itu perencanaan pengaturan jadwal yang tepat sangat dibutuhkan untuk menjadi solusi dari masalah ini.

Luasnya ruang lingkup penelitian dan terbatasnya kemampuan untuk melakukan penelitian dapat menyebabkan tidak terarahnya penelitian dan menurunkan kontrol yang dilakukan peneliti untuk melakukan penelitian. Untuk melakukan penelitian yang terarah maka subjek penelitian ini dibatasi hanya pada lintas Tanah Abang-Rangkasbitung, yang selanjutnya disebut Green Line.

Rumusan masalah yang akan dibahas adalah:

- Bagaimana cara mengidentifikasi keterlambatan keberangkatan KRL Green Line?

- Bagaimana mengklasifikasikan tingkat keterlambatan keberangkatan KRL Green Line?

- Apa saja solusi yang bisa diterapkan untuk mengatasi masalah keterlambatan keberangkatan KRL Green Line?

Adapun beberapa tujuan dari penelitian ini adalah:

- Mengidentifikasi keterlambatan keberangkatan KRL Green Line di Stasiun Jurangmangu.

- Mengklasifikasikan tingkat keterlambatan keberangkatan KRL Green Line di Stasiun Jurangmangu.

- Menentukan solusi yang dapat diterapkan untuk mengatasi masalah keterlambatan keberangkatan KRL Green Line di Stasiun Jurangmangu.

\section{Kereta rel listrik}

Kereta Rel Listrik umumnya disebut KRL adalah kereta rel yang bergerak dengan motor listrik sebagai penggerak utama. Motor listrik adalah alat yang mengubah energi listrik menjadi energi mekanik. Sumber tenaga dari motor listrik adalah listrik yang termasuk dalam kategori bahan bakar hijau. Listrik merupakan bahan bakar yang mengeluarkan emisi gas rumah kaca yang minim, apalagi bila menggunakan sumber tenaga dari tenaga air, angin, sel surya, ataupun nuklir (Abubakar). Kelebihan KRL adalah tarif yang bisa dijangkau oleh berbagai golongan, mulai dari anak sekolah, mahasiswa, dan pegawai. Selain tarif yang murah, jangkauan dari KRL sangat jauh karena bisa mencakup seluruh Jabodetabek.

\section{Hubungan kualitas pelayanan dengan kepuasan penumpang}

Kinerja suatu penyedia jasa dapat dikatakan sudah baik apabila sudah bisa memberikan kepuasan kepada penumpang. Logo PT. Kereta Commuter Indonesia yang memiliki arti selalu mengutamakan pelanggan dibanding dengan perusahaan dan memiliki pemikiran terbuka dalam melayani pelanggan, dapat dijadikan dasar dalam pengoperasian kereta api. Pengguna layanan bisa menilai suatu layanan baik atau buruk tergantung pada kemampuan penyedia jasa untuk memenuhi harapan pengguna layanan secara konsisten (Andayani). Oleh karena itu maka sebaiknya tujuan dari jasa pelayanan KRL adalah untuk memberikan kepuasan pada pelanggan

Kualitas pelayanan dan kepuasan konsumen penting karena penilaian konsumen terhadap suatu layanan merupakan konstruksi yang menentukan kemungkinan adanya penggunaan layanan ulang dari konsumen dan akhirnya akan mempengaruhi keberhasilan penyedia layanan (Iacobucci, Ostrom and Grayson). Dalam hal ini, ketepatan waktu dapat memberikan kepuasan terhadap penumpang kereta. Ketepatan waktu menjadi salah satu faktor mengapa penumpang KRL memilih transportasi ini dibanding dengan transportasi lain seperti Transjakarta dan ojek online. Kesetiaan terhadap suatu layanan merupakan salah satu aset dari penyedia layanan yang harus dijaga dengan mempertahankan kualitas pelayanan karena diperlukan waktu yang lama untuk menerima loyalitas dari pelanggan (Kotler). 


\section{Standar pelayanan minimum}

Standar Pelayanan Minimal (SPM) adalah ketentuan tentang jenis dan mutu pelayanan dasar yang merupakan urusan wajib tentang pelayanan yang berhak diperoleh setiap warga atau pengguna jasa layanan secara minimal. Standar Pelayanan Minimal (SPM) juga merupakan spesifikasi teknis tentang tolak ukur pelayanan minimum yang diberikan oleh penyedia jasa layanan kepada pengguna jasa layanan (Meikalyan). Standar Pelayanan Minimum (SPM) kereta api diatur dalam "Peraturan Mentri Perhubungan Indonesia Nomor 63 Tahun 2019 Tentang Standar Pelayanan Minimum Angkutan Orang Dengan Kereta Api”. Dalam penelitian ini, SPM yang diperhatikan adalah tentang ketepatan waktu.

Dalam Standar Pelayanan Minimal (SPM) kereta api, Kereta Api Listrik (KRL) termasuk dalam jenis kereta api perkotaan. SPM kereta api mengatur bahwa untuk kereta antarkota, keterlambatan maksimum adalah $10 \%$ dari total waktu perjalanan yang dijadwalkan. Sedangkan untuk kereta perkotaan, keterlambatan maksimum adalah $20 \%$ dari total waktu perjalanan yang dijadwalkan. Tetapi keterlambatan tersebut tidak termasuk akibat gangguan selama perjalanan (cuaca atau kecelakaan).

\section{Grafik Perjalanan Kereta Api (GAPEKA)}

Keterlambatan kedatangan kereta dapat diketahui jika waktu kedatangan tersebut tidak sesuai dengan Grafik Perjalanan Kereta Api (GAPEKA) yang dikeluarkan oleh PT. Kereta Api Indonesia. Menurut "Peraturan Pemerintah Republik Indonesia Nomor 72 Tahun 2009 Tentang Lalu Lintas Dan Angkutan Kereta Api”, pelaksanaan perjalanan kereta api yang dimulai dari stasiun keberangkatan, bersilang, bersusulan, dan berhenti di stasiun tujuan diatur berdasarkan GAPEKA (Muctar).

Grafik Perjalanan Kereta Api biasanya dibagi menjadi 8 atau 4 grid vertikal yang menunjukkan pembagian waktu tergantung kepadatan lalu lintas kereta. Grid horizontal jumlahnya menggambarkan stasiun yang dilewati atau dituju kereta. GAPEKA menampilkan data-data yang berupa jadwal perjalanan kereta api dalam satu hari, posisi dan jarak antar stasiun serta kecepatan yang diijinkan (Hidayat, Anggoro and Sarinah). Grafik Perjalanan Kereta Api dibuat oleh tim dari PT. Kereta Api Indonesia (PT. KAI) dan disahkan oleh Kementerian Perhubungan melalui Direktorat Jenderal Perkeretaapian.

Sudah jelas bahwa Grafik Perjalanan Kereta Api mengambil peranan penting dalam pengoperasian kereta api. Oleh karena itu penyusunan GAPEKA harus dilakukan dengan teliti dan efisien. Selain untuk kepuasan pelanggan, ketepatan waktu kedatangan kereta juga cukup penting jika dilihat dari faktor keselamatan dalam kereta api.

\section{Nilai waktu}

Di kota besar khususnya DKI Jakarta sebagai pusat pemerintahan dan pusat perekonomian, kemacetan adalah salah satu masalah besar yang dihadapi. Akibat dari kemacetan tersebut, pengguna jalan akan kehilangan banyak waktu dengan adanya peningkatan waktu perjalanan. Nilai waktu tersebut dalam sektor transportasi diartikan sebagai sejumlah uang yang disediakan seseorang atau pengguna layanan transportasi untuk dikeluarkan guna menghemat satu unit waktu perjalanan.

Nilai waktu dibagi menjadi 2 komponen yaitu biaya potensial sumber dan biaya pengorbanan yang diinterpretasikan sebagai nilai bagi pelaku perjalanan dalam menggunakan waktu untuk beraktivitas misalnya bekerja atau belajar. Selanjutnya dijelaskan bahwa biaya ketidaknyamanan dapat diinterpretasikan sebagai tingkat ketidaksenangan, kebosanan atau aspek negatif yang dapat menghilangkan waktu perjalanan. Faktor-faktor yang berpengaruh dalam menentukan nilai manfaat waktu perjalanan adalah panjang perjalanan, jenis kendaraan, periode waktu, maksud perjalanan, kondisi lingkungan, jenis kelamin dan usia (Friedrich.M and Lohmiller.J)

\section{Gap analysis}

Analisis gap atau analisis kesenjangan umum digunakan pada praktek bisnis. analisis gap digunakan untuk menentukan segala sesuatu yang perlu diperhatikan untuk mencapai suatu tujuan. Secara sederhana analisis gap hanya dianggap sebagai analisis kebutuhan semata yaitu untuk menilai kebutuhan saja. Analisis gap dapat juga diartikan sebagai perbandingan keadaan sesungguhnya dengan keadaan yang direncanakan.

Sebagai sebuah metoda, analisis gap digunakan sebagai alat untuk mengevaluasi kesenjangan yang terjadi dengan keadaan yang direncanakan sebelumnya. Evaluasi merupakan persoalan fakta dan logika dan lebih penting dari yang paling penting. Analisis ini juga bertujuan untuk mengurangi kesenjangan yang terjadi. Lebih dari itu analisis ini juga memperkirakan waktu, biaya, dan sumber daya yang dibutuhkan untuk mencapai keadaan perusahaan atau sesuatu yang diharapkan pada perencanaan sebelumnya.

Terdapat 3 komponen utama dari analisis gap: 
Jurangmangu)

- Daftar karakteristik dari situasi sekarang atau keadaan yang sebenarnya terjadi

- Daftar apa yang diperlukan untuk mencapai keadaan yang direncanakan

- Daftar kesenjangan apa yang ada dan perlu diidentifikasi

Analisis ini akan memicu suatu perusahaan untuk memikirkan apa yang dibutuhkan untuk mencapai suatu tujuan yang sudah direncanakan. Jadi dapat dikatakan bahwa analisis gap adalah studi yang dibuat untuk mencari tahu apakah tujuan dari sebuah rencana sudah terlaksana atau belum. Analisis gap mengidentifikasikan gap atau kesenjangan antara sesuatu yang perlu dilakukan dengan yang belum atau tidak bisa dilakukan. Dengan sendirinya solusi-solusi akan hadir untuk mencapai tujuan pada saat gap fungsi ditemukan.

Langkah-langkah analisis gap dalam bisnis yang disimpulkan oleh para ahli adalah sebagai berikut:

- Memastikan suatu tujuan dapat diakomodasikan oleh implementasi sistem yang baru dan memastikan areaarea yang penting bagi organisasi yang memberikan nilai tambah bagi perusahaan dalam mencapai tujuan tersebut

- Menentukan sejauh mana kebutuhan dapat diakomodir oleh sistem yang baru

- Menentukan alternaif dan merekomendasikan solusi untuk mengatasi kesenjangan yang ada

\section{METODE PENELITIAN}

\section{Jenis penelitian}

Jenis penelitian yang dilakukan adalah penelitian deskriptif kuantitatif guna untuk menggambarkan karateristik individu, karateristik perjalanan, dan persepsi keterlambatan menurut penumpang yang menggunakan jasa transportasi KRL Green Line.

\section{Lokasi penelitian}

Penelitian dilaksanakan pada Stasiun Jurangmangu dengan alasan:

- Stasiun Jurangmangu adalah salah satu stasiun kelas 3/kecil pada lintas KRL Greeen Line.

- Lokasi Stasiun Jurangmangu yang dekat dengan universitas, pemukiman, dan pusat perbelanjaan akan mempengaruhi keberagaman karateristik.

\section{Responden/objek studi}

Responden/objek studi pada penelitian ini adalah penumpang KRL Green Line di Stasiun Jurangmangu. Diharapkan semua responden mampu memberikan informasi yang jujur dan tepat agar penelitian ini dapat menghasilkan output yang valid.

\section{Metode pengumpulan data}

Data pada penelitian ini terdapat dua hal yaitu:

- Data Primer yang merupakan data kuesioner online untuk menggambarkan karateristik individu, karateristik perjalanan, dan persepsi keterlambatan.

- Data Sekunder yang merupakan Grafik Perjalanan Kereta Api (GAPEKA) yang didapat melalui PT. KCI.

\section{Metode analisis data}

Metode analisis yang akan digunakan adalah Gap Analysis. Gap Analysis digunakan untuk mengklasifikasikan tingkat keterlambatan, kemudian hasil tersebut bisa didapat hubungan Gap antara GAPEKA dan realisasi. Gap yang dimaksud adalah kesenjangan antara kategori terlambat wajar hingga terlambat parah. Lalu dari tiap kategori wajar hingga parah dianalisis lagi kesenjangan atara terlambat menurut konsumen dan terlambat menurut pihak penyelenggara. Hasil yang didapat diharapkan mampu merepresentasikan hasil publik terhadap ketepatan kedatangan KRL di Stasiun Jurangmangu.

\section{HASIL DAN PEMBAHASAN}

\section{Data responden}

Data responden didapat melalui penyebaran kuesioner online dengan menggunakan Google Forms. Penyebaran kuesioner ini ditujukan kepada masyarakat yang sering menggunakan jasa transportasi KRL Green Line. Didapatkan hasil responden sebanyak 130 data yang pernah menggunakan jasa transportasi KRL Green Line dan sebanyak 31 orang yang berangkat dari dan bertujuan ke Stasiun Jurangmangu. 


\section{Persepsi keterlambatan keberangkatan responden}

Persepsi responden (kereta lebih cepat dari jadwal) dapat dilihat pada Gambar 1 dan Gambar 2.

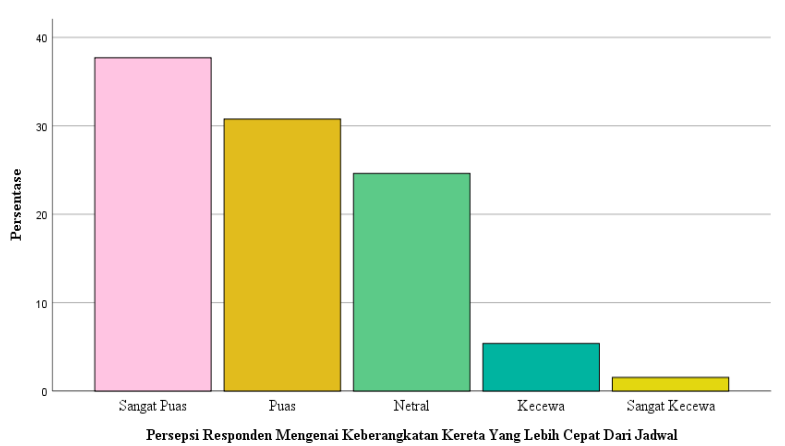

Gambar 1. Persepsi responden Green Line (kereta lebih cepat dari jadwal)

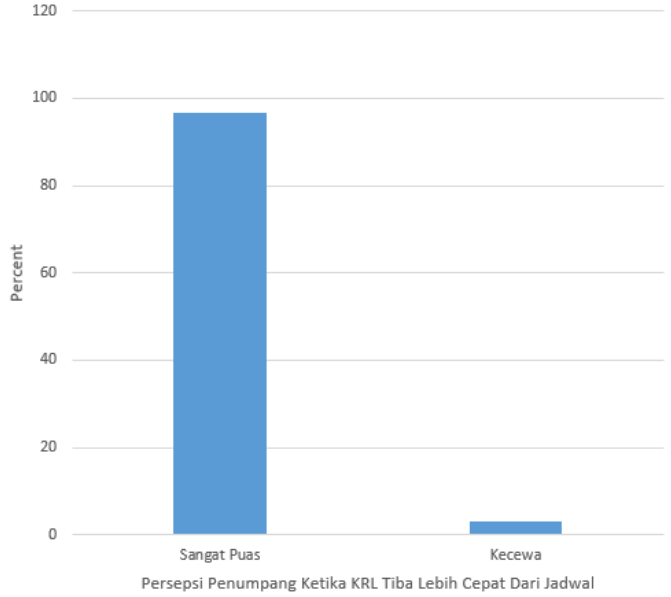

Gambar 2. Persepsi responden Stasiun Jurangmangu (kereta lebih cepat dari jadwal)

Persepsi responden (kereta tepat jadwal) dapat dilihat pada Gambar 3 dan Gambar 4.

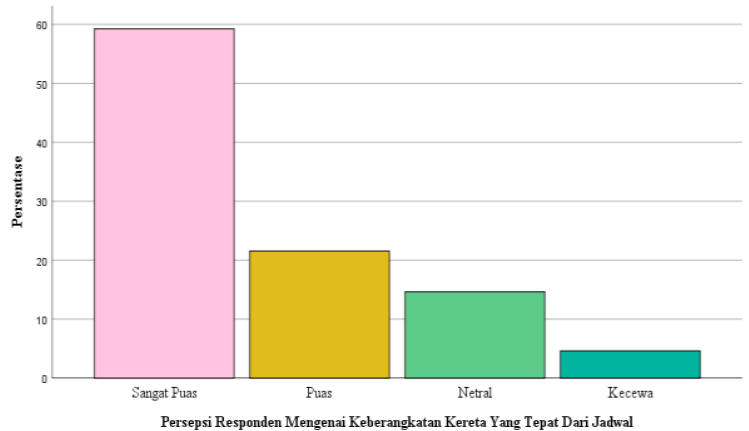

Gambar 3. Persepsi responden Green Line (kereta tepat jadwal)

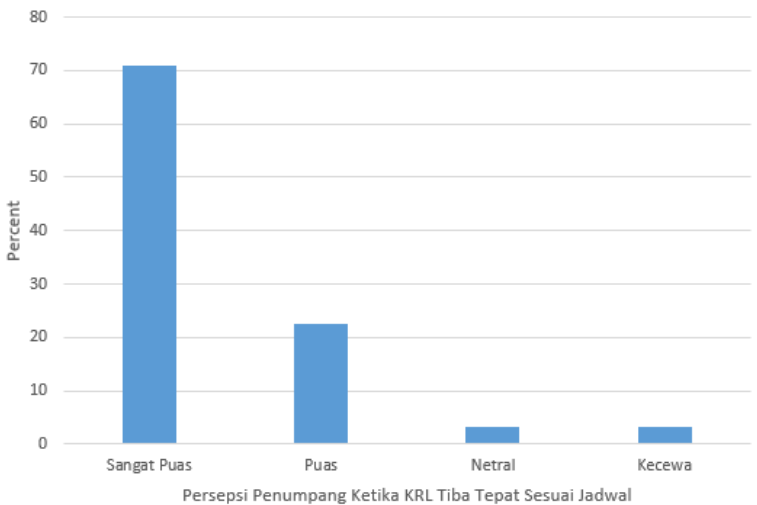

Gambar 4. Persepsi responden Stasiun Jurangmangu (kereta tepat jadwal) 
Persepsi responden (kereta terlambat $\leq 3$ menit) dapat dilihat pada Gambar 5 dan Gambar 6 .

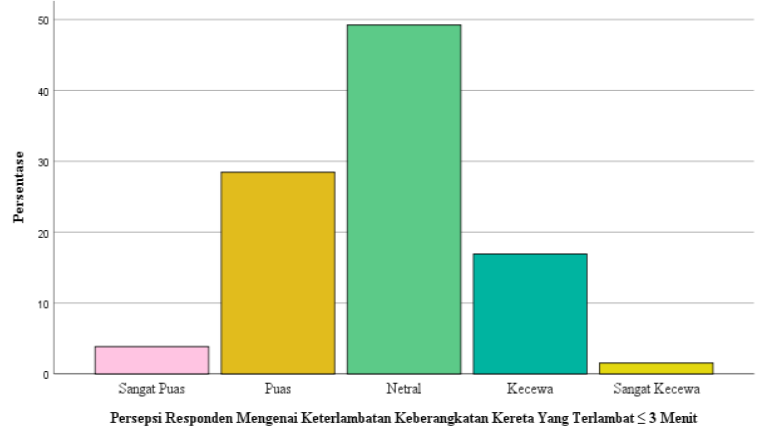

Gambar 5. Persepsi responden Green Line (kereta terlambat $\leq 3$ menit)

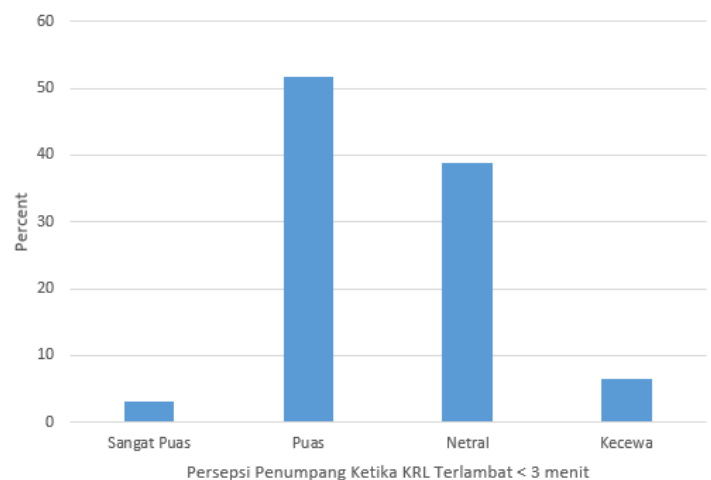

Gambar 6. Persepsi responden Stasiun Jurangmangu (kereta terlambat $\leq 3$ menit)

Persepsi responden (kereta terlambat 3-5 menit) dapat dilihat pada Gambar 7 dan Gambar 8.

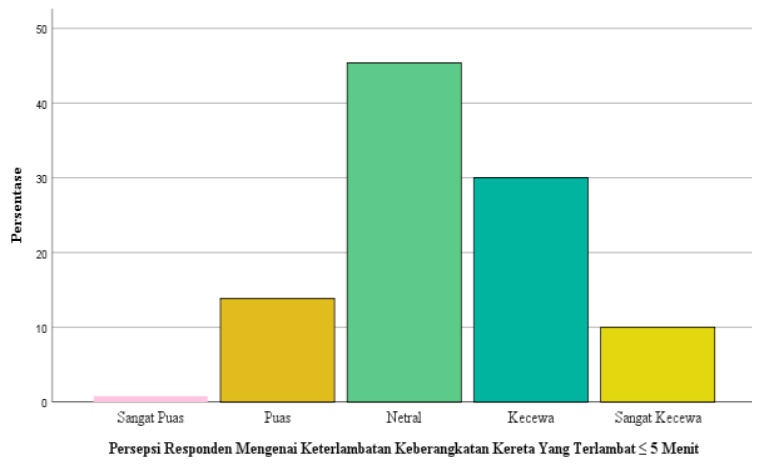

Gambar 7. Persepsi responden Green Line (kereta terlambat $\leq 5$ menit)

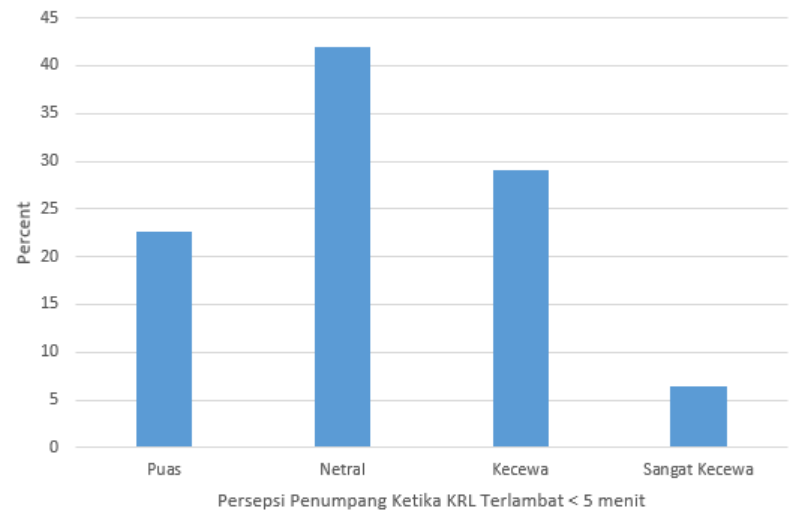

Gambar 8. Persepsi responden Stasiun Jurangmangu (kereta terlambat $\leq 5$ menit)

Persepsi responden (kereta terlambat 5-10 menit) dapat dilihat pada Gambar 9 dan Gambar 10.

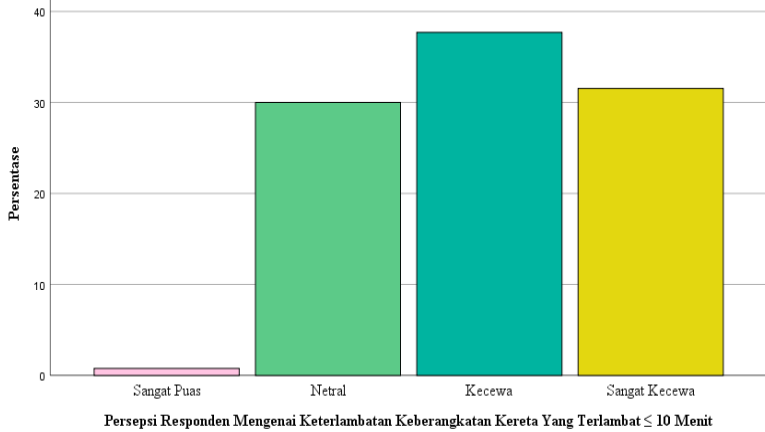

Gambar 9. Persepsi responden Green Line (kereta terlambat $\leq 10$ menit)

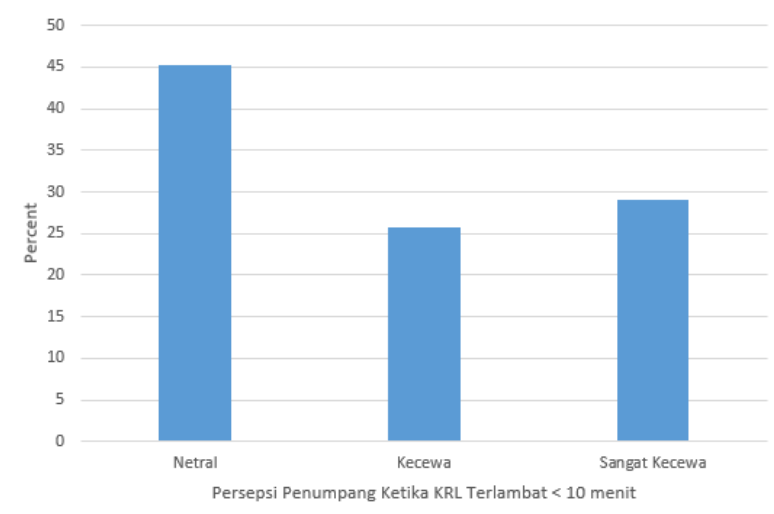

Gambar 10. Persepsi responden Stasiun Jurangmangu (kereta terlambat $\leq 10$ menit) 
Persepsi responden (kereta terlambat 10-15 menit) dapat dilihat pada Gambar 11 dan Gambar 12.

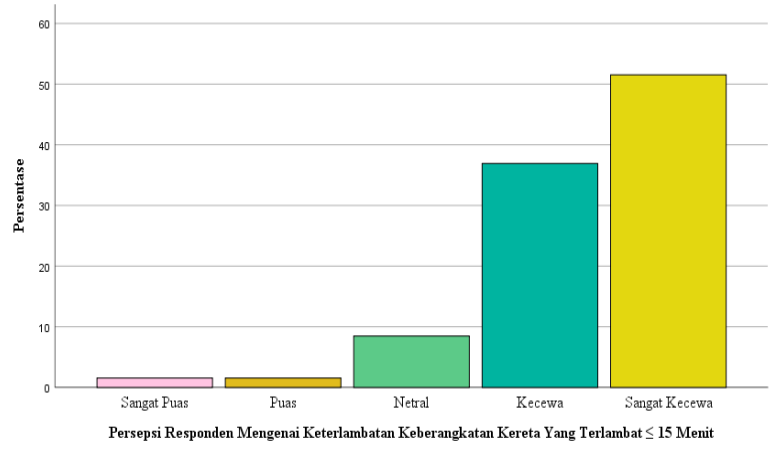

Gambar 11. Persepsi responden Green Line (kereta terlambat $\leq 15$ menit)

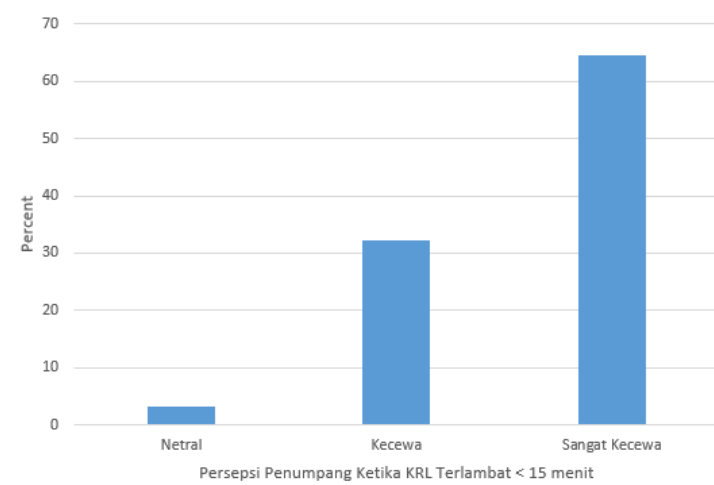

Gambar 12 Persepsi responden Stasiun Jurangmangu (kereta terlambat $\leq 15$ menit)

Persepsi responden (kereta terlambat $\geq 15$ menit) dapat dilihat pada Gambar 13 dan Gambar 14 .

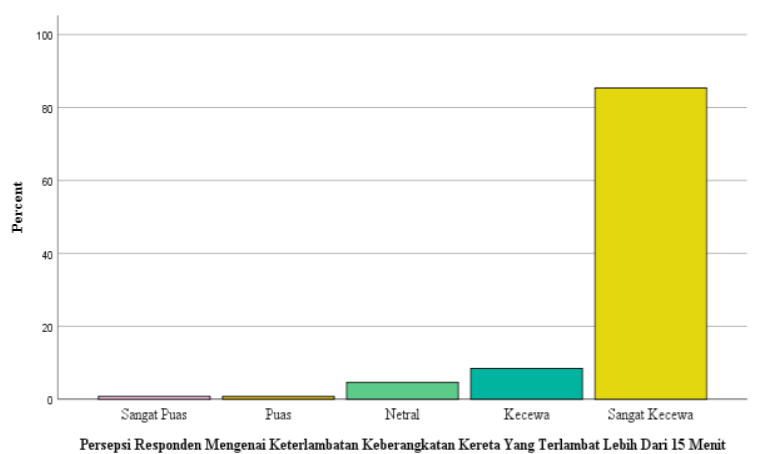

Gambar 13. Persepsi responden Green Line (kereta terlambat $\geq 15$ menit)

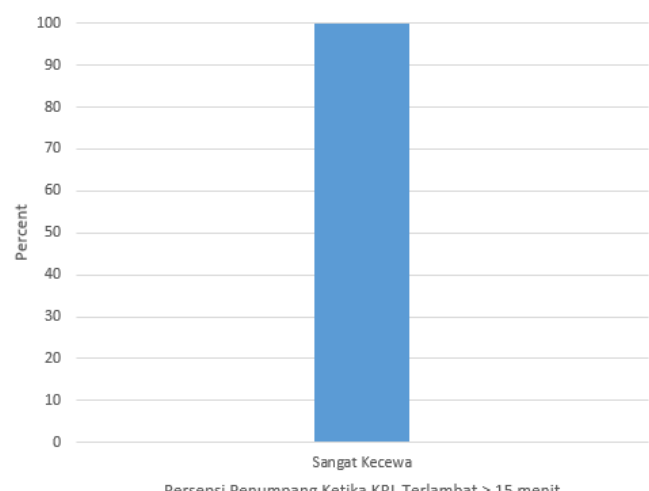

Gambar 14 Persepsi responden Stasiun Jurangmangu (kereta terlambat $\geq 15$ menit)

Pendapat responden ketika kereta terlambat apakah selalu diberikan informasi oleh petugas dapat dilihat pada Gambar 15 dan Gambar 16.

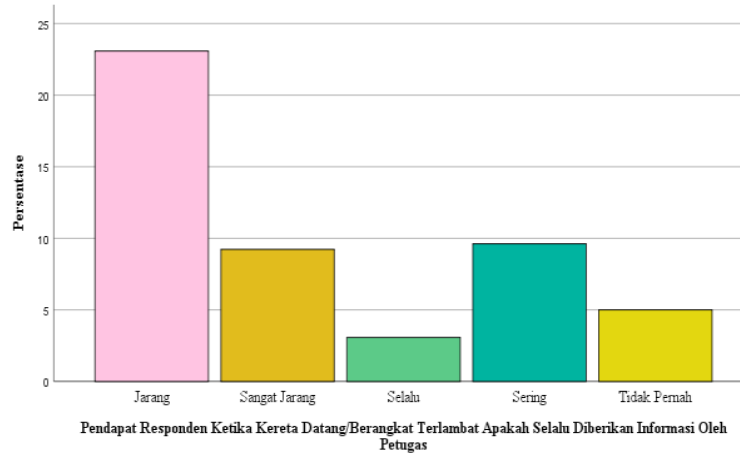

Gambar 15. Pendapat responden Green Line ketika kereta terlambat apakah selalu diberikan informasi oleh petugas

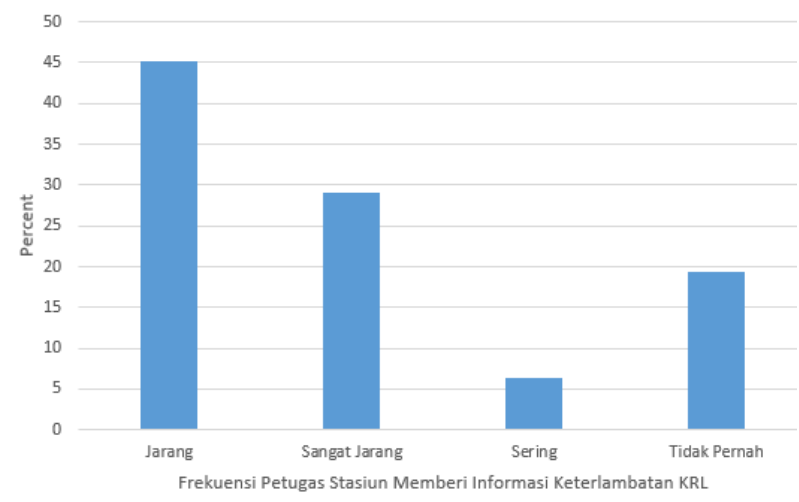

Gambar 16. Pendapat responden Jurangmangu ketika kereta terlambat apakah selalu diberikan informasi oleh petugas 


\section{Hasil analisis data persepsi keterlambatan responden Green Line}

Perhitungan toleransi keterlambatan penumpang di jalur Green Line dan persentasenya dapat dilihat pada Tabel 1 dan Tabel 2. Kemudian untuk mengetahui berapa toleransi keterlambatan oleh penumpang dapat dilihat pada Gambar 17.

Tabel 1. Toleransi keterlambatan penumpang di jalur Green Line

\begin{tabular}{cccccc}
\hline \multirow{2}{*}{$\begin{array}{c}\text { Waktu } \\
\text { Keterlambatan }\end{array}$} & \multicolumn{3}{c}{ Menerima } & \multicolumn{2}{c}{ Tidak Menerima } \\
\cline { 2 - 6 } & Sangat Puas & Puas & Netral & Kecewa & $\begin{array}{c}\text { Sangat } \\
\text { Kecewa }\end{array}$ \\
\hline <3 menit & 5 & 37 & 64 & 22 & 2 \\
$3-5$ menit & 1 & 18 & 59 & 39 & 13 \\
$5-10$ menit & 1 & 0 & 39 & 49 & 41 \\
$10-15$ menit & 2 & 2 & 11 & 48 & 67 \\
$\geq 15$ menit & 1 & 1 & 6 & 11 & 111 \\
\hline
\end{tabular}

Tabel 2. Persentase toleransi keterlambatan jalur Green Line

\begin{tabular}{cccc}
\hline Waktu Keterlambatan & Menerima & Tidak Menerima & Total \\
\hline$\leq 3$ menit & $82 \%$ & $18 \%$ & $100 \%$ \\
$3-5$ menit & $60 \%$ & $40 \%$ & $100 \%$ \\
$5-10$ menit & $31 \%$ & $69 \%$ & $100 \%$ \\
$10-15$ menit & $12 \%$ & $88 \%$ & $100 \%$ \\
$\geq 15$ menit & $6 \%$ & $94 \%$ & $100 \%$ \\
\hline
\end{tabular}

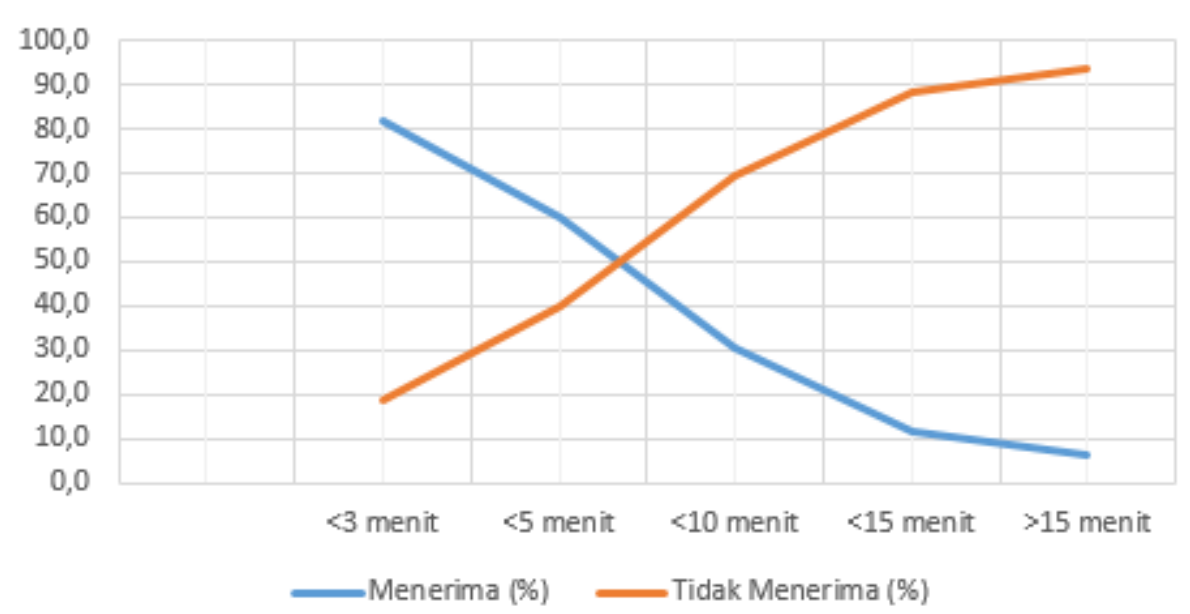

Gambar 17. Toleransi keterlambatan oleh penumpang jalur Green Line

Dari hasil analisis didapatkan bahwa toleransi keterlambatan menurut penumpang jalur Green Line adalah kurang dari 5 menit.

\section{Hasil analisis data persepsi keterlambatan responden Stasiun Jurangmangu}

Perhitungan toleransi keterlambatan penumpang di Stasiun Jurangmangu dan persentasenya dapat dilihat pada Tabel 3 dan Tabel 4. Kemudian untuk mengetahui berapa toleransi keterlambatan oleh penumpang dapat dilihat pada Gambar 18. 
Tabel 3. Toleransi keterlambatan oleh penumpang di Stasiun Jurangmangu

\begin{tabular}{cccccc}
\hline Waktu & \multicolumn{3}{c}{ Menerima } & \multicolumn{2}{c}{ Tidak Menerima } \\
\cline { 2 - 6 } Keterlambatan & Sangat Puas & Puas & Netral & Kecewa & $\begin{array}{c}\text { Sangat } \\
\text { Kecewa }\end{array}$ \\
\hline$\leq 3$ menit & 1 & 16 & 12 & 2 & 0 \\
3-5 menit & 0 & 7 & 13 & 9 & 2 \\
5-10 menit & 0 & 0 & 14 & 8 & 9 \\
10-15 menit & 0 & 0 & 1 & 10 & 20 \\
$\geq 15$ menit & 0 & 0 & 0 & 0 & 31 \\
\hline
\end{tabular}

Tabel 4. Persentase toleransi keterlambatan di Stasiun Jurangmangu

\begin{tabular}{cccc}
\hline Waktu Keterlambatan & Menerima & Tidak Menerima & Total \\
\hline$\leq 3$ menit & $93.5 \%$ & $6.5 \%$ & $100 \%$ \\
$3-5$ menit & $64.5 \%$ & $35.5 \%$ & $100 \%$ \\
$5-10$ menit & $45.2 \%$ & $54.8 \%$ & $100 \%$ \\
$10-15$ menit & $3.2 \%$ & $96.8 \%$ & $100 \%$ \\
$\geq 15$ menit & $0 \%$ & $100 \%$ & $100 \%$ \\
\hline
\end{tabular}

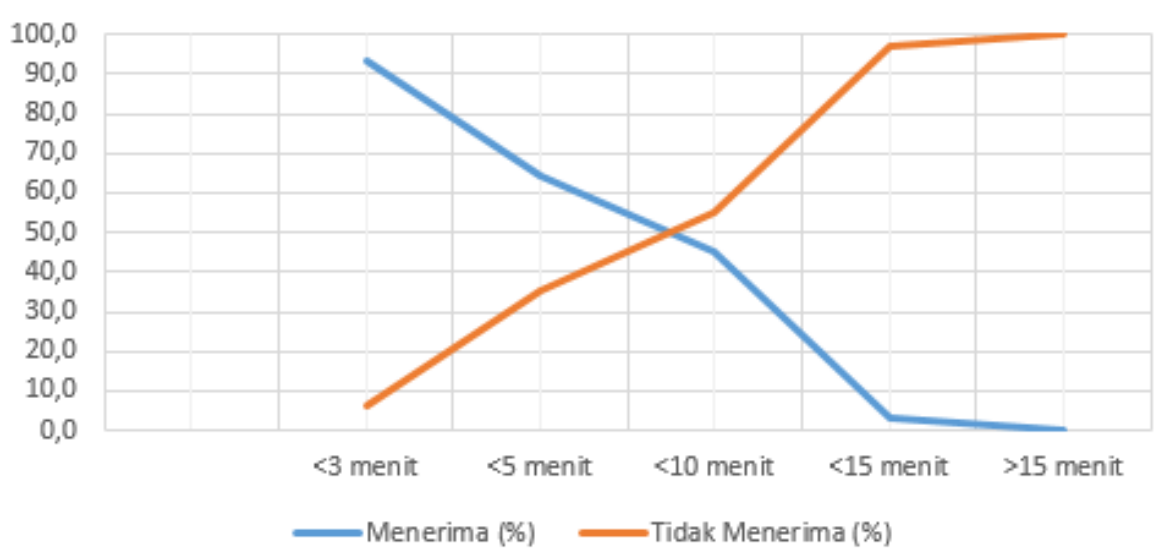

Gambar 18 Toleransi keterlambatan oleh penumpang Stasiun Jurangmangu

Didapatkan bahwa toleransi keterlambatan menurut penumpang Stasiun Jurangmangu adalah kurang dari 10 menit.

\section{Toleransi keterlambatan menurut Peraturan Menteri}

Toleransi keterlambatan menurut Peraturan Menteri dapat dilihat perhitungannya pada Tabel 5.

Tabel 5. Toleransi keterlambatan menurut Peraturan Menteri

\begin{tabular}{cccc}
\hline Stasiun & Stasiun & Waktu & Toleransi \\
Keberangkatan & Tujuan & Tempuh (menit) & Keterlambatan (menit) \\
\hline Tanah Abang & Jurangmangu & 24 & 4,8 \\
Palmerah & Jurangmangu & 18 & 3,6 \\
Kebayoran & Jurangmangu & 11 & 2,2 \\
\hline
\end{tabular}


Tabel 5. Toleransi keterlambatan menurut Peraturan Menteri (Lanjutan)

\begin{tabular}{|c|c|c|c|}
\hline Stasiun & Stasiun & Waktu & Toleransi \\
\hline Keberangkatan & Tujuan & Tempuh (menit) & Keterlambatan (menit) \\
\hline Pondok Ranji & Jurangmangu & 3 & 0,6 \\
\hline Sudimara & Jurangmangu & 3 & 0,6 \\
\hline Rawa Buntu & Jurangmangu & 9 & 1,8 \\
\hline Serpong & Jurangmangu & 13 & 2,6 \\
\hline Cisauk & Jurangmangu & 17 & 3,4 \\
\hline Cicayur & Jurangmangu & 22 & 4,4 \\
\hline Parung Panjang & Jurangmangu & 28 & 5,6 \\
\hline Cilejit & Jurangmangu & 40 & 8 \\
\hline Daru & Jurangmangu & 44 & 8,8 \\
\hline Tenjo & Jurangmangu & 50 & 10 \\
\hline Tigaraksa & Jurangmangu & 54 & 10,8 \\
\hline Cikoya & Jurangmangu & 60 & 12 \\
\hline Maja & Jurangmangu & 63 & 12,6 \\
\hline Citeras & Jurangmangu & 74 & 14,8 \\
\hline RangkasBitung & Jurangmangu & 89 & 17,8 \\
\hline
\end{tabular}

Setelah dilakukan perhitungan toleransi keterlambatan menurut Peraturan Menteri, maka didapat rata-rata waktu toleransi keterlambatan adalah 6 menit.

\section{Penilaian realisasi waktu keberangkatan terhadap waktu program keberangkatan}

Waktu keterlambatan didapat dari selisih waktu antara program dan realisasi keberangkatan. Keterlambatan yang terjadi di Stasiun Jurangmangu saat pagi hari dapat dilihat pada Tabel 6 dan Tabel 7.

Tabel 6. Realisasi waktu keberangkatan Stasiun Jurangmangu (menuju Tanah Abang) pagi: 06:00 - 08:00

\begin{tabular}{ccccc}
\hline $\begin{array}{c}\text { Kode } \\
\text { Kereta }\end{array}$ & Asal Kereta & $\begin{array}{c}\text { Program } \\
\text { Keberangkatan }\end{array}$ & $\begin{array}{c}\text { Realisasi } \\
\text { Keberangkatan }\end{array}$ & $\begin{array}{c}\text { Keterlambatan } \\
\text { (Menit) }\end{array}$ \\
\hline 1933 & Parung Panjang & $06: 08$ & $06: 09$ & $00: 01$ \\
1935 & Serpong & $06: 18$ & $06: 19$ & $00: 01$ \\
1937 & Rangkas Bitung & $06: 28$ & $06: 30$ & $00: 02$ \\
1939 & Sudimara & $06: 38$ & $06: 40$ & $00: 02$ \\
1941 & Maja & $06: 48$ & $06: 51$ & $00: 03$ \\
1943 & Rangkas Bitung & $06: 58$ & $06: 59$ & $00: 01$ \\
1945 & Parung Panjang & $07: 08$ & $07: 09$ & $00: 01$ \\
1947 & Serpong & $07: 18$ & $07: 19$ & $00: 01$ \\
1949 & Rangkas Bitung & $07: 28$ & $07: 30$ & $00: 02$ \\
1951 & Parung Panjang & $07: 38$ & $07: 40$ & $00: 02$ \\
1953 & Maja & $07: 48$ & $07: 49$ & $00: 01$ \\
1955 & Rangkas Bitung & $07: 58$ & $07: 59$ & $00: 01$ \\
\hline
\end{tabular}


Rata-rata waktu keterlambatan Stasiun Jurangmangu (menuju Tanah Abang) pagi: 06:00 - 08:00 adalah 1 menit 30 detik.

Tabel 7. Realisasi waktu keberangkatan Stasiun Jurangmangu (dari Tanah Abang) pagi: 06:00 - 08:00

\begin{tabular}{ccccc}
\hline $\begin{array}{c}\text { Kode } \\
\text { Kereta }\end{array}$ & $\begin{array}{c}\text { Tujuan Akhir } \\
\text { Kereta }\end{array}$ & $\begin{array}{c}\text { Program } \\
\text { Keberangkatan }\end{array}$ & $\begin{array}{c}\text { Realisasi } \\
\text { Keberangkatan }\end{array}$ & $\begin{array}{c}\text { Keterlambatan } \\
\text { (Menit) }\end{array}$ \\
\hline 1922 & Parung Panjang & $06: 19$ & $06: 20$ & $00: 01$ \\
1924 & Serpong & $06: 29$ & $06: 30$ & $00: 01$ \\
1928 & Parung Panjang & $06: 39$ & $06: 40$ & $00: 01$ \\
1930 & Rangkas Bitung & $06: 49$ & $06: 52$ & $00: 03$ \\
1932 & Maja & $06: 59$ & $07: 00$ & $00: 01$ \\
1934 & Parung Panjang & $07: 09$ & $07: 11$ & $00: 02$ \\
1936 & Rangkas Bitung & $07: 19$ & $07: 20$ & $00: 01$ \\
1938 & Serpong & $07: 29$ & $07: 30$ & $00: 01$ \\
1940 & Parung Panjang & $07: 39$ & $07: 41$ & $00: 02$ \\
1942 & Rangkas Bitung & $07: 49$ & $07: 50$ & $00: 01$ \\
1944 & Parung Panjang & $07: 59$ & $08: 01$ & $00: 02$ \\
\hline
\end{tabular}

Rata-rata waktu keterlambatan Stasiun Jurangmangu (dari Tanah Abang) pagi: 06:00 - 08:00 adalah 1 menit 27 detik. Keterlambatan yang terjadi di Stasiun Jurangmangu saat siang hari dapat dilihat pada Tabel 8 dan Tabel 9.

Tabel 8. Realisasi waktu keberangkatan Stasiun Jurangmangu (menuju Tanah Abang) siang: 11:00 - 13:00

\begin{tabular}{ccccc}
\hline $\begin{array}{c}\text { Kode } \\
\text { Kereta }\end{array}$ & Asal Kereta & $\begin{array}{c}\text { Program } \\
\text { Keberangkatan }\end{array}$ & $\begin{array}{c}\text { Realisasi } \\
\text { Keberangkatan }\end{array}$ & $\begin{array}{c}\text { Keterlambatan } \\
\text { (Menit) }\end{array}$ \\
\hline 1993 & Parungpanjang & $11: 08$ & $11: 09$ & $00: 01$ \\
1997 & Parungpanjang & $11: 28$ & $11: 29$ & $00: 01$ \\
1999 & Parungpanjang & $11: 38$ & $11: 39$ & $00: 01$ \\
2001 & Maja & $11: 48$ & $11: 49$ & $00: 01$ \\
2003 & Parungpanjang & $11: 58$ & $11: 58$ & $00: 00$ \\
2005 & Serpong & $12: 28$ & $12: 28$ & $00: 00$ \\
2007 & Parungpanjang & $12: 38$ & $12: 39$ & $00: 01$ \\
2009 & Maja & $12: 48$ & $12: 48$ & $00: 00$ \\
2011 & Rangkasbitung & $12: 58$ & $12: 59$ & $00: 01$ \\
\hline
\end{tabular}

Rata-rata waktu keterlambatan Stasiun Jurangmangu (menuju Tanah Abang) siang: 11:00 - 13:00 adalah 40 detik. 
Analisis Tingkat Ketepatan Waktu KRL Commuter Line

Felix Jonathan Christy, et al.

Lintas Tanah Abang-Rangkasbitung (Studi Kasus: Stasiun

Jurangmangu)

Tabel 9. Realisasi waktu keberangkatan Stasiun Jurangmangu (dari Tanah Abang) siang: 11:00 - 13:00

\begin{tabular}{ccccc}
\hline $\begin{array}{c}\text { Kode } \\
\text { Kereta }\end{array}$ & $\begin{array}{c}\text { Tujuan Akhir } \\
\text { Kereta }\end{array}$ & $\begin{array}{c}\text { Program } \\
\text { Keberangkatan }\end{array}$ & $\begin{array}{c}\text { Realisasi } \\
\text { Keberangkatan }\end{array}$ & $\begin{array}{c}\text { Keterlambatan } \\
\text { (Menit) }\end{array}$ \\
\hline 1982 & Rangkasbitung & $11: 09$ & $11: 10$ & $00: 01$ \\
1986 & Serpong & $11: 29$ & $11: 30$ & $00: 01$ \\
1988 & Rangkasbitung & $11: 39$ & $11: 41$ & $00: 02$ \\
1990 & Parungpanjang & $11: 49$ & $11: 50$ & $00: 01$ \\
1992 & Parungpanjang & $11: 59$ & $12: 01$ & $00: 02$ \\
1994 & Rangkasbitung & $12: 09$ & $12: 09$ & $00: 00$ \\
1998 & Parungpanjang & $12: 29$ & $12: 31$ & $00: 02$ \\
2000 & Rangkasbitung & $12: 39$ & $12: 40$ & $00: 01$ \\
2002 & Parungpanjang & $12: 54$ & $12: 56$ & $00: 02$ \\
\hline
\end{tabular}

Rata-rata waktu keterlambatan Stasiun Jurangmangu (dari Tanah Abang) siang: 11:00 - 13:00 adalah 1 menit 20 detik.

Keterlambatan yang terjadi di Stasiun Jurangmangu saat sore hari dapat dilihat pada Tabel 10 dan Tabel 11.

Tabel 10. Realisasi waktu keberangkatan Stasiun Jurangmangu (menuju Tanah Abang) sore: 16:00 - 18:00

\begin{tabular}{ccccc}
\hline $\begin{array}{c}\text { Kode } \\
\text { Kereta }\end{array}$ & Asal Kereta & $\begin{array}{c}\text { Program } \\
\text { Keberangkatan }\end{array}$ & $\begin{array}{c}\text { Realisasi } \\
\text { Keberangkatan }\end{array}$ & $\begin{array}{c}\text { Keterlambatan } \\
\text { (Menit) }\end{array}$ \\
\hline 2049 & Serpong & $16: 18$ & $16: 20$ & $00: 02$ \\
2051 & Rangkasbitung & $16: 28$ & $16: 29$ & $00: 01$ \\
2053 & Parungpanjang & $16: 38$ & $16: 39$ & $00: 01$ \\
2055 & Maja & $16: 48$ & $16: 49$ & $00: 01$ \\
2057 & Rangkasbitung & $16: 58$ & $17: 00$ & $00: 02$ \\
2059 & Parungpanjang & $17: 08$ & $17: 09$ & $00: 01$ \\
2061 & Serpong & $17: 18$ & $17: 19$ & $00: 01$ \\
2063 & Rangkasbitung & $17: 28$ & $17: 30$ & $00: 02$ \\
2065 & Parungpanjang & $17: 38$ & $17: 39$ & $00: 01$ \\
2067 & Maja & $17: 48$ & $17: 49$ & $00: 01$ \\
2069 & Rangkasbitung & $17: 58$ & $18: 00$ & $00: 02$ \\
\hline
\end{tabular}

Rata-rata waktu keterlambatan Stasiun Jurangmangu (menuju Tanah Abang) sore: 16:00 - 18:00 adalah 1 menit 22 detik. 
Tabel 11 Realisasi waktu keberangkatan Stasiun Jurangmangu (dari Tanah Abang) sore :16:00 - 18:00

\begin{tabular}{ccccc}
\hline $\begin{array}{c}\text { Kode } \\
\text { Kereta }\end{array}$ & $\begin{array}{c}\text { Tujuan Akhir } \\
\text { Kereta }\end{array}$ & $\begin{array}{c}\text { Program } \\
\text { Keberangkatan }\end{array}$ & $\begin{array}{c}\text { Realisasi } \\
\text { Keberangkatan }\end{array}$ & $\begin{array}{c}\text { Keterlambatan } \\
\text { (Menit) }\end{array}$ \\
\hline 2036 & Rangkasbitung & $16: 09$ & $16: 10$ & $00: 01$ \\
2038 & Maja & $16: 19$ & $16: 21$ & $00: 02$ \\
2040 & Serpong & $16: 29$ & $16: 30$ & $00: 01$ \\
2042 & Rangkasbitung & $16: 39$ & $16: 40$ & $00: 01$ \\
2044 & Parungpanjang & $16: 49$ & $16: 50$ & $00: 01$ \\
2046 & Maja & $16: 59$ & $17: 01$ & $00: 02$ \\
2050 & Parungpanjang & $17: 19$ & $17: 21$ & $00: 02$ \\
2052 & Serpong & $17: 29$ & $17: 31$ & $00: 02$ \\
2054 & Parungpanjang & $17: 39$ & $17: 40$ & $00: 01$ \\
2056 & Rangkasbitung & $17: 49$ & $17: 52$ & $00: 03$ \\
2058 & Maja & $17: 59$ & $18: 01$ & $00: 02$ \\
\hline
\end{tabular}

Rata-rata waktu keterlambatan Stasiun Jurangmangu (dari Tanah Abang) sore:16:00 - 18:00 adalah 1 menit 38 detik.

Hasil analisis rata-rata waktu keterlambatan di Stasiun Jurangmangu:

- Rata-rata waktu keterlambatan Stasiun Jurangmangu (menuju Tanah Abang) Pagi: 06:00 - 08:00 adalah 1 menit 30 detik.

- Rata-rata waktu keterlambatan Stasiun Jurangmangu (dari Tanah Abang) Pagi: 06:00 - 08:00 adalah 1 menit 27 detik.

- Rata-rata waktu keterlambatan Stasiun Jurangmangu (menuju Tanah Abang) Siang: 11:00 - 13:00 adalah 40 detik.

- Rata-rata waktu keterlambatan Stasiun Jurangmangu (dari Tanah Abang) Siang: 11:00 - 13:00 adalah 1 menit 20 detik.

- Rata-rata waktu keterlambatan Stasiun Jurangmangu (menuju Tanah Abang) Sore: 16:00 - 18:00 adalah 1 menit 22 detik.

- Rata-rata waktu keterlambatan Stasiun Jurangmangu (dari Tanah Abanag) Sore: 16:00 - 18:00 adalah 1 menit 38 detik.

Setelah mendapatkan nilai waktu keterlambatan yang merupakan nilai realisasi waktu keberangkatan kereta api pada Stasiun Jurangmangu dikurangi dengan nilai program waktu keberangkatan dari GAPEKA, dilakukan penilaian waktu keterlambatan tersebut dengan acuan sebagai berikut:

- Peraturan Menteri Perhubungan Nomor: PM 63 Tahun 2019 tentang Standar Pelayanan Minimum Untuk Angkutan Orang Dengan Kereta Api

- Hasil dari persepsi pengguna kereta jalur Green Line mengenai keterlambatan mengenai keterlambatan kereta

- Hasil dari persepsi pengguna kereta di Stasiun Jurangmangu mengenai keterlambatan kereta

\section{KESIMPULAN DAN SARAN}

\section{Kesimpulan}

Dari hasil dan pembahasan pada penelitian ini dapat ditarik beberapa kesimpulan yaitu:

- Terdapat 3 tolak ukur atau batas toleransi keterlambatan keberangkatan kereta sebagai berikut: 
- Peraturan Menteri Perhubungan Nomor: PM 63 TAHUN 2019 tentang Standar Pelayanan Minimum Untuk Angkutan Orang Dengan Kereta Api menetapkan batas toleransi keterlambatan adalah 20\% dari waktu tempuh yaitu sebesar 6 menit.

- Hasil dari persepsi pengguna KRL jalur Green Line mengenai keterlambatan kereta yaitu sebesar 5 menit.

- Hasil dari persepsi pengguna KRL di Stasiun Jurangmangu mengenai keterlambatan kereta yaitu sebesar 10 menit.

- Dari data 10 Februari 2020 diperoleh data survei kedatangan dan keberangkatan di Stasiun Jurangmangu pada jam sibuk pagi (06.00-08.00), siang (11.00-13.00), dan sore (16.00-18.00). Dari hasil analisis menunjukkan bahwa tingkat keterlambatan kedatangan dan keberangkatannya masih di bawah toleransi menurut Peraturan Menteri PM 63 Tahun 2019 dan persepsi penumpang.

\section{Saran}

Berdasarkan hasil penelitian yang telah dilakukan terdapat beberapa saran yang sekiranya dapat menjadi masukan untuk objek studi dan penelitian selanjutnya. Beberapa saran tersebut diantaranya adalah sebagai berikut:

- Kesimpulan yang didapat dari hasil penelitian menunjukan bahwa Stasiun Jurangmangu berada di bawah batas toleransi menurut PM no 63 Tahun 2019 dan persepsi pengguna KRL, sehingga manajemen perlu mempertahankan dan terus meningkatkan kualitas pelayanan Stasiun Jurangmangu.

- Penelitian ini dilakukan pada saat pandemi Corona Virus terjadi di Indonesia, sehingga:

- Hasil data kuesioner merupakan hasil dari responden dalam jaringan (Google Form) sehingga hasil yang didapat tidak maksimal, dan responden merupakan dominan dari Stasiun Tanah Abang. Disarankan untuk yang melanjutkan penelitian ini untuk dilengkapi dengan kuesioner berbasis offline (tatap muka) sehingga data lebih mewakili responden.

- Pelaksanaan survei lapangan terhadap realisasi keberangkatan KRL Green Line di Stasaiun Jurangmangu hanya di lakukan pada 1 hari kerja, disarankan untuk melakukan survei pada 2 hari kerja dan 1 hari libur untuk mendapatkan hasil yang lebih mewakili dan maksimal.

\section{DAFTAR PUSTAKA}

Abubakar, Iskandar. Manajemen Lalu Lintas, Suatu pendekatan untuk mengelola dan mengendalikan lalu lintas. TRANSINDO Gastama Media, 2012.

Andayani, Wiwik and Agung Yuniarinto dan Djumilah Zain. Analisis Kualitas Pelayanan Dan Pengaruhnya Terhadap Kepuasan Konsumen (2010).

Friedrich.M dan Lohmiller.J. Factor influencing the travel time reliabily of motorway sections, Publication of Proceedings of the 6th International Symposium Networks for Mobility. Stuttgart, 2012.

Hidayat, Masjraul, Djayo Anggoro dan Sarinah. Faktor Keterlambatan Kedatangan Kereta Api Penumpang Dan Kinerja Daerah Operasi 1 Jakarta (2018): Jurnal Manajemen Bisnis Transportasi Dan Logistik.

Iacobucci, Dawn, Amy Ostrom dan Kent Grayson. Distinguishing Service Quality and Customer Satisfaction: The Voice of the Consumer (1995): Journal of Consumer Psycology.

Kotler, Philip. Manajemen Pemasaran. Jakarta: PT Prenhallindo, 2002.

Kuswati, Atik S. On Time Performance (OTP) KRL Ekspress Jabodetabek (2010).

Meikalyan, Rizzal. Studi Komparasi Standar Pelayanan Minimal (SPM) Bus Trans Jogja (2016).

Muctar, Edi. Pengaruh Kualitas Pelayanan, Ketepatan Waktu Dan Customer Experience Terhadap Kepuasan Penumpang Kereta Api Kalijaga Jurusan Semarang-Solo (2019). 